\title{
ANALYSIS OF WORK PLACE AND MODE CHOICE BEHAVIOR IN METRO MANILA EMPLOYING PANEL DATA*
}

\author{
パネルデータを用いたメトロマニラにおける勤務地移動、交通機関選択行動の分析
}

\author{
by Hussein S. LIDASAN** \\ Haruo ISHIDA ${ }^{* * *}$ \\ Takeshi KUROKAWA ***** \\ Mamoru TANIGUCHI***** \\ Eiji OHNO $* * * * *$
}

\section{INTRODUCTION}

The pace of urbanization in developing countries has surpassed those in developed countries. Coupled with fast economic development, this has brought tremendous changes not only on the structure of the cities but also on people's socio-economic conditions and behavior. To cope with these, governments have introduced and implemented new long-term and short-term transport policies and measures such as mass transit systems and travel demand management schemes. These led further to changes in people's travel behavior.

Current conventional travel behavior analytical tools seem inadequate to comprehend the effects of these changes over time. A recent approach in understanding dynamic changes that follow the same samples over time, known as panel (or longitudinal) analysis can be one tool that may supplement transportation planning practices in developing countries. The theoretical advantages of panel analysis make it attractive in the changing socio-economic conditions to explore the economic and mode choice decisions of people in developing countries. However, it is important that the performance of panel analysis be evaluated first before it can be initiated.

In this regard, the purpose of this paper is to ascertain and gauge the potential of using panel data in analyzing whether or not decisions of people will vary over time given the continuously changing conditions in the region. The paper is organized as follows: a) a brief depiction of the panel survey in Metro Manila and the data sets in Chapter 2; b) analysis of socio-economic changes in Chapter 3; c) analysis of to-work mode choice behavior in Chapter

*Keywords: panel data, work place log- linear model, mode choice panel model, developing countries

**Ph. D. Assistant Professor, University of the Philippines, School of Urban \& Regional Planning, Diliman, Quezon City 1101, Philippines

***Dr. Eng., Associate Professor, University of Tsukuba, Institute of Socio-Economic Planning, Tennodai 1-1-1, Tsukuba-shi, Japan 305

****Dr. Eng., Professor, Tokyo Institute of Technology, Interdisciplinary Graduate School of Science and Engineering, 4259 Nagatsuda, Midori-ku, Yokohama, Kanagawa Japan 226 *****Dr. Eng., Assistant Professor, Okayama University, Department of Environmental and Civil Engineering, 2-1-1 Tsushima-Naka, Okayama 700

******Dr. Eng., Assistant Professor, University of Tsukuba, Institute of Socio-Economic Planning, Tennodai 1-1-1, Tsukuba-shi, Japan 305 
4 ; and finally, e) the conclusions of the paper in chapter 5 .

\section{THE METRO MANILA PANEL SURVEY}

\subsection{Study Area and Survey Design and Conduct}

A three-wave panel survey was conducted in Metro Manila, the capital region of the Philippines having an area of $636 \mathrm{sq}$. kms. with a population of. 7.80 million as of the last census in 1990 (roughly $13.0 \%$ of the national population). The initial wave of the survey was conducted on the first quarter of 1987 along the present LRT line 1 corridor (Appendix 1), while the second wave was in the second quarter of 1990 in the same corridor and augmented in the latter part of the year to include the proposed LRT line 2 corridor. The third wave was in the second quarter of 1992 covering both LRT corridors.

The purposive-quota-proportional sampling (i.e., with respect to income distribution and density) was employed in the first wave in order to have proper representation of the population in the area as much as possible. A list of the 1987 wave samples was prepared together with their corresponding home addresses, name of household heads and members, sex and age of members for the 1990 wave along LRT line 1 corridor. The list prepared for the 1992 wave was from both LRT corridors of the 1990 wave. In the conduct of the latter surveys, those on the lists were given priority. When those on the list were not available new members of households were interviewed. New households interviewed as refreshments of those not covered were done using the same sampling method as in the first wave. The survey was in the form of a personal interview (door-to-door) survey.

\subsection{Results of the Survey and the Panel Data Sets}

The survey results of the three waves are given in Table 1 .

After the data from the respective household and member samples were coded and encoded, the samples were compared to institute the panel samples. Since the first wave was along LRT 1 and the latter waves were along LRT 1 and 2 the 1987 samples were compared with the 1990 March samples and all 1990 samples were compared with the 1992 samples. The comparison keys were: a) household level - address, family names and length of residence at given address, and $b$ ) individual level - exact names of respondents and sex. Table 2 summarizes the results of comparison.

Table 1 - Results of the Survey

\begin{tabular}{|c|c|c|}
\hline WAVE & NO. OF HOUSEHOLDS & $\begin{array}{c}\text { NO. OF MEMBERS } \\
\text { INTERVIEWED }\end{array}$ \\
\hline 1987 & 899 & 1437 \\
\hline 1990 & 1261 & 4126 \\
\hline 1992 & 1167 & 4029 \\
\hline
\end{tabular}

Note: a) Only working household members in 1987 wave while all members in the other waves

b) 1990 March: 872 HHs 3039 members (LRTI)

1990 Aug. : 296 HHs 1087 members (LRT2)

1990 Wave : 1251 HHs 4125 members 
Table 2 above implies that the two sets have almost the same degrees of relation in both household and member levels. However the ' $87-' 90$ set has slightly higher relation. The related member samples were further examined according to the consistency in their civil status, changes in occupation, employment and workplace. According to the extent of relation, all the samples were classified into four categories (Table 3). Although precisely matched Category 1 samples should be used, samples from both Categories 1 \& 2 of '87-'90 panel data set which have higher matching ratio shall also constitute the necessary data for the succeeding chapters in order to increase the number of samples.

Table 2 Results of Matching

\begin{tabular}{|c|c|c|}
\hline A. Household Level & $87-90$ & $90-92$ \\
\hline No. of Households & $892(100.0 \%)$ & $1261(100.0 \%)$ \\
\hline Matching Households & $447(50.1 \%)$ & $631(50.0 \%)$ \\
Unmatching Households & $445(49.9 \%)$ & $630(50.0 \%)$ \\
\hline B. Member Level & $87-90$ & $90-92$ \\
\hline No. of Members & $1437(100.0 \%)$ & $4029(100.0 \%)$ \\
\hline Matching Members & $514(35.8 \%)$ & $1308(31.7 \%)$ \\
Unmatching Members & $923(64.2 \%)$ & $2818(68.3 \%)$ \\
\hline
\end{tabular}

Table 3 - Category Definition

\begin{tabular}{|c|c|c|c|c|c||}
\hline Category & Age Difference & Civil Status & $\begin{array}{c}\text { Changes in } \\
\text { Occupation } \\
\text { Employment } \\
\text { Workplace }\end{array}$ & $87-90$ & $90-92$ \\
\hline 1. Panel & Exact & Consistent & No Change & $\begin{array}{c}245 \\
(47.7 \%)\end{array}$ & $\begin{array}{c}410 \\
(31.3 \%)\end{array}$ \\
\hline $\begin{array}{c}\text { 2. Likely } \\
\text { Panel }\end{array}$ & Less Exact & Consistent & No Change & $\begin{array}{c}157 \\
(30.5 \%)\end{array}$ & $\begin{array}{c}370 \\
(28.3 \%)\end{array}$ \\
\hline $\begin{array}{c}\text { 3. Less } \\
\text { Likely }\end{array}$ & Not Exact & Consistent & No Change & $\begin{array}{c}37 \\
(7.2 \%)\end{array}$ & $\begin{array}{c}166 \\
(12.7 \%)\end{array}$ \\
\hline $\begin{array}{l}\text { 4. Not } \\
\text { Panel }\end{array}$ & Not Exact & Inconsistent & Changes & $\begin{array}{c}75 \\
(14.6 \%)\end{array}$ & $\begin{array}{c}312 \\
(27.7 \%)\end{array}$ \\
\hline
\end{tabular}

The results of the survey show that the potential of conducting the panel survey in Metro Manila is high. However, there was a low turn-out at the individual level compared to the household level.

\section{Analysis of Socio-economic Changes and their Association}

\subsection{Outline of Analytical Approach}

An illustration of the theoretical merits of panel analysis in describing the changes in one attribute is shown in Section 3.2. Logit log-linear modeling was used to determine the relationships of the attributes in Sections 3.3 and 3.4. A logit log-linear model analyses categorical qualitative data sets and one attribute is selected as the dependent variable. 
Parameters of other independent variables are estimated so as to have a good estimate of frequencies of the dependent variable. In a logit log-linear model, two statistics are calculated: $Z$-value for the explanatory power of each independent variable and $\lambda^{2}$ (chisquare) for the over-all goodness of fit.

\subsection{Description of Changes in Workplaces}

The distribution of the panel members according to their workplaces in 1987 and 1990 are given in Figure 1. Ignoring the darker shaded portion, what is shown is only the marginal distribution of the changes in workplaces. This describes the cross-sectional dispersion of the samples. The actual changes that transpired could not be measured. However, the actual changes between the two periods could be gauged when the panel data are used to describe the changes. The darker portions show the dispersion of those in the same workplaces while the lighter segments depict those with changes. Thus, the merits of using panel data can be visualized by the above illustration. Both marginal and actual changes can be measured with panel data.

Fig. 1 Distribution of Workplace (\%)

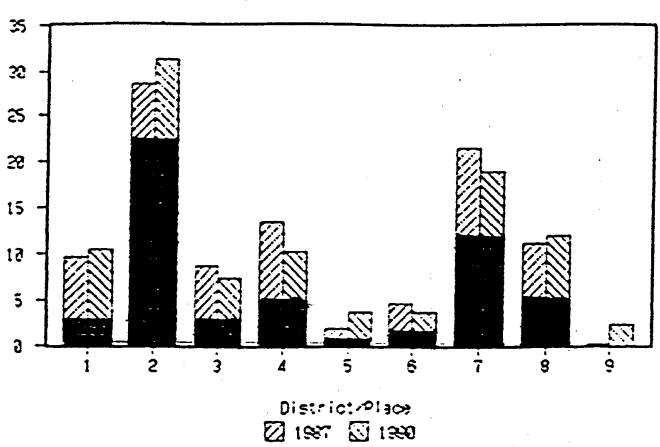

Legend:

$1 \quad 1$ st \& 2nd, Manila

23 rd \& 4th, Manila

3 Pasay

4 Quezon City

5 Caloocan, South

6 Parañaque

7 Makati, M. Manila

8 Others, M. Manila

9 Outside M. Manila

\subsection{Logit Log-Linear Model of Association of Attributes}

The relationships of the attributes can be viewed by looking at the hierarchy of decisions of people and the association of the levels of the hierarchy. People tend to make long-term decisions with respect to their socio-economic attributes such as workplace, employment, etc., implying that decisions are made over time. Decisions concerning which modes to take for a trip are considered short-term decisions. However, these short-term decisions are influenced by the changes in the socio-economic attributes of people.

To examine this, several logit log-linear models were calibrated to have changes in to-work mode (CHS) as a dependent variable and changes in workplace (WP), employment (EMP), and occupation (OCC) as independent variables. Good fitness of the model shown in Table 4 shows the relationship between long-term independent variables and short-term mode choice behavior. WP revealed the most significant effect on changes in mode choice.

An interesting observation that can also be seen from the model is that changes in employment (EMP) have a negative effect on workplace while changes in occupation (OCC), as in shifts in work place, have a positive effect. The relatively high value of the constant implies that other effects not specified in the model are evident. 
Table 4 Logit Log-Linear Mode Choice Model

\begin{tabular}{|c|c|c|c|c|}
\hline Parameter & Coeff. & Reg'n Coeff. & Antilog & Z-Value \\
\hline CHS CONST & -0.031 & -0.262 & 1.299 & -1.448 \\
CHS by WP & 0.164 & 0.328 & 1.388 & 1.834 \\
CHS by EMP & -0.015 & -0.029 & 0.971 & -0.189 \\
CHS by OCP & 0.099 & 0.199 & 1.220 & -0.081 \\
\hline \multicolumn{5}{|c||}{ Expected Odds 2.136 } \\
\hline \multicolumn{5}{|c|}{ Likelihood Chi-square $=18.71 \mathrm{df}=12 \mathrm{p}=0.10$} \\
Person Chi-square $=17.08 \mathrm{df}=12 \mathrm{p}=0.15$ \\
\hline
\end{tabular}

(Note: the degrees-of-freedom (df) is calculated as the number of logits for which $\mathrm{f}_{\mathrm{jk}}$ is positive less than the number of parameters specified for the model, $\mathrm{P}$ is the probability of the $\lambda^{2}$ value under the given $\mathrm{df}$.)

\subsection{Logit Log-Linear Model of Associations Among Attributes}

The relationships of the effects of selected attributes to changes in workplace illustrate the association among the attributes. All the variables specified in the workplace models are dichotomous variables - no change and change, except for the income variable, which is polytomous - no change, increase, decrease. A no change in work place is modeled over changes in the other variables. Four workplace models are presented here to depict the implications of adding a new direct effect or interaction-effect parameter on the model.

Model 1 gives the model of workplace involving direct effects of employment and occupation (Table 5). The positive signs of the coefficients imply that the direct effects are determinant of no changes in workplace. Changes in employment is a key factor in the model. This is supported by its high Z-value. Model 2 shows direct and interaction effects (Table 6). Although the expected odds has increased slightly, the inclusion of an interactioneffect parameter has minimal influence on the model. This is shown by the low coefficient and $\mathrm{Z}$-value of the interaction-effect parameter.

Table 5 Logit-Log-Linear Workplace Model 1

\begin{tabular}{|c|c|c|c|c|}
\hline Parameter & Coeff. & Reg'n Coeff. & Antilog & Z-Value \\
\hline WP CONST & -0.001 & -0.001 & 0.999 & -0.010 \\
WP by EMP & 0.441 & 0.881 & 2.413 & 7.435 \\
WP by OCP & -0.064 & -0.128 & 1.137 & 1.160 \\
\hline \multicolumn{4}{|c|}{ Expected Odds 2.74} \\
\hline \multicolumn{5}{|c|}{ Likelihood Chi-square $=56.5 \mathrm{df}=37 \mathrm{p}=0.27$} \\
& Person Chi-square $=45.88 \mathrm{df}=37 \mathrm{p}=0.18$ \\
\hline
\end{tabular}

Models 3 and 4 show the inclusion of new variables in the model : monthly individual income (MIN1) and monthly household income (MIN2), shown on Tables 7 and 8. The expected odds of the panel members to remain in their workplace has decreased implying that changes in income have relation to changes in workplace. As in Model 2, the inclusion of an interaction-effect parameter had small influence on the model. Finally, all the models show good estimation and fitness as reflected by the chi-square values. 
Table 6 Logit Log-Linear Workplace Model 2

\begin{tabular}{|c|c|c|c|c|}
\hline Parameter & Coeff. & Reg'n Coeff. & Antilog & Z-Value \\
\hline WP CONST & -0.011 & -0.022 & 0.978 & -0.181 \\
WP by EMP & 0.448 & 0.895 & 2.447 & 7.338 \\
WP by OCP & 0.050 & -0.101 & 1.106 & 0.827 \\
WP by EMP & 0.033 & 0.066 & 1.068 & 0.540 \\
by OCP & & & \\
\hline \multicolumn{4}{|c|}{ Expected Odds 2.83} \\
\hline \\
Likelihood Chi-square $=56.21 \mathrm{df}=37 \mathrm{p}=0.02$ \\
Person Chi-square $=45.75 \mathrm{df}=37 \mathrm{p}=0.15$ \\
\hline
\end{tabular}

Table 7 Logit Log-Linear Workplace Model 3

\begin{tabular}{|c|c|c|c|c|}
\hline Parameter & Coeff. & Reg'n Coeff. & Antilog & Z-Value \\
\hline WP CONST & 0.057 & 0.115 & 1.122 & 0.722 \\
WP by EMP & 0.445 & 0.889 & 2.433 & 7.409 \\
WP by OCP & 0.074 & 0.147 & 1.158 & 1.319 \\
WP by MIN1 & -0.186 & -0.373 & 0.830 & -2.009 \\
WP by MIN2 & 0.002 & 0.012 & 1.012 & 0.069 \\
\hline \multicolumn{4}{|c|}{ Expected Odds 2.66 } \\
\hline \multicolumn{5}{|c|}{ Likelihood Chi-square $=52.09 \mathrm{df}=36 \mathrm{p}=0.04$} \\
Person Chi-square $=41.89 \mathrm{df}=36 \mathrm{p}=0.23$ \\
\hline
\end{tabular}

Table 8 Logit Log-Linear Workplace Model 4

\begin{tabular}{|c|c|c|c|c|}
\hline Parameter & Coeff. & Reg'n Coeff. & Antilog & $Z$-Value \\
\hline WP CONST & 0.002 & 0.005 & 1.005 & 0.044 \\
\hline WP by EMP & 0.447 & 0.893 & 2.442 & 1.287 \\
\hline WP by $\mathrm{OCP}$ & 0.101 & 0.202 & 1.224 & 1.287 \\
\hline $\begin{array}{l}\text { WP by } \mathrm{OCP} \\
\text { by MINI }\end{array}$ & -0.099 & -0.198 & 0.820 & -1.068 \\
\hline $\begin{array}{l}\text { WP by } O C P \\
\text { by MIN2 }\end{array}$ & -0.012 & -0.024 & 0.976 & -0.138 \\
\hline \multicolumn{5}{|c|}{ Expected Odds } \\
\hline \multicolumn{5}{|c|}{$\begin{aligned} \text { Likelihood Chi-square } & =55.34 \mathrm{df}=36 \quad \mathrm{p}=0.02 \\
\text { Person Chi-square } & =41.89 \mathrm{df}=36 \quad \mathrm{p}=0.14\end{aligned}$} \\
\hline
\end{tabular}

\section{ANALYSIS OF TO-WORK MODE CHOICE DECISIONS}

\subsection{Outline of Analysis}

This chapter focuses on the use of panel data in examining to-work mode choice decisions. The main objective here is to determine whether the panel members' socioeconomic changes affect their to-work mode choice decisions. Parallel to this is to compare 
cross-sectional and panel data in modeling disaggregate mode choice models and gauge the performance of the panel model. The indices of comparison are a) stability of parameters, b) similarity test, c) t-test, and d) time transferability test.

The elementary assumptions in panel model of serial correlation of the error terms are partially relaxed in the estimation of the logit mode choice models. This is done in order to simplify calculation of the model. The serial correlation assumption is partially relaxed for two reasons: a) heterogeneity and misspecification can be ignored if the models are estimated properly; and b) true state dependence can be conditionally disregarded due to the changing socio-economic conditions of the panel members.

Description of the data sets are first presented to define their characteristics and to justify the partial relaxation of the serial correlation assumption.

\subsection{Description of the Data Sets}

The mode choice set in Metro Manila consists mainly of three public modes : jeepney (a para-transit), bus and LRT, and car. Table 9 shows a prevalent decline in the distribution of the actual modes used for to-work trips in the total samples data sets (1987TS and 1990TS). The high chi-squares of the total samples data sets reveal the differences in the composition of the samples as compared to the panel data sets.

Table 9 Modal Share Distribution

\begin{tabular}{|c|c|c|c|c|c|c|}
\hline & Jeepney & Bus & LRT & Car & TOTAL & $\begin{array}{c}\text { CHI- } \\
\text { SQUARE }\end{array}$ \\
\hline 1987TS & $\begin{array}{c}506 \\
(58.8)\end{array}$ & $\begin{array}{c}125 \\
(14.5)\end{array}$ & $\begin{array}{c}165 \\
(19.2)\end{array}$ & $\begin{array}{c}164 \\
(7.4)\end{array}$ & $\begin{array}{c}860 \\
(100.0)\end{array}$ & \multirow{2}{*}{16.84} \\
\cline { 1 - 6 } 1990TS & $\begin{array}{c}405 \\
(57.6)\end{array}$ & $\begin{array}{c}86 \\
(12.3)\end{array}$ & $\begin{array}{c}94 \\
(13.4)\end{array}$ & $\begin{array}{c}117 \\
(16.7)\end{array}$ & $\begin{array}{c}702 \\
(100.0)\end{array}$ & \\
\hline 1987PS & $\begin{array}{c}79 \\
(56.0)\end{array}$ & $\begin{array}{c}17 \\
(12.1)\end{array}$ & $\begin{array}{c}31 \\
(22.0)\end{array}$ & $\begin{array}{c}14 \\
(9.9)\end{array}$ & $\begin{array}{c}141 \\
(100)\end{array}$ & \multirow{2}{*}{7.56} \\
\cline { 1 - 5 } 1990PS & $\begin{array}{c}78 \\
(55.3)\end{array}$ & $\begin{array}{c}18 \\
(12.8)\end{array}$ & $\begin{array}{c}18 \\
(12.8)\end{array}$ & $\begin{array}{c}27 \\
(19.1)\end{array}$ & $\begin{array}{c}141 \\
(100)\end{array}$ & \\
\hline POOLED & $\begin{array}{c}156 \\
(55.3)\end{array}$ & $\begin{array}{c}36 \\
(12.8)\end{array}$ & $\begin{array}{c}49 \\
(17.4)\end{array}$ & $\begin{array}{c}41 \\
(14.5)\end{array}$ & $\begin{array}{c}282 \\
(100)\end{array}$ & \\
\hline
\end{tabular}

Note: TS - Total Samples PS - Panel Samples POOLED - Pooled Panel Samples

\subsection{Results of Model Estimation and Comparison}

The specification of the models include three generic LOS variables (out-of-vehicle travel time: OVTT, in-vehicle travel time: IVTT, and total cost:TOC), one specific-to-car variable (income: INC), and three constants (for jeepney, bus, and LRT). The mode choice models estimated are given in Tables 10 and 11 . As a whole all the models show good estimation results as reflected by their indices (i.e., \%-hit). The total samples models have more significant parameters than the models with panel data. This is due to the less number of panel samples. And assuming no structural change in mode choice behavior, the number of insignificant parameters was reduced when panel data were pooled.

In Table 12, the association of the respective models are shown by the similarity indices among the models. It is observed that the 1987TS and 1990TS models closely resemble each other. On the other hand, the 1987PS model shows strong similarities with 
the total samples models than the 1990PS model. The panel model (POOLED) resembles closely all the models except the 1990PS. 1987PS and 1990PS models reveal dissimilarities between them.

Table 10 Total Samples Mode Choice Models

\begin{tabular}{|c|c|c|c|c|c|}
\hline & & \multicolumn{2}{|c|}{1987 TS } & \multicolumn{2}{|c|}{1990 TS } \\
\hline \multicolumn{2}{|c|}{ Variables } & $\theta$ & $t$-value & $\theta$. & $t$-value \\
\hline LOS & $\begin{array}{l}\text { OVTT (G) } \\
\text { IVTT (G) } \\
\text { TOC (G) }\end{array}$ & $\begin{array}{l}-0.186 \\
-0.015 \\
-0.008\end{array}$ & $\begin{array}{l}-3.77 \\
-2.66 \\
-0.10^{*}\end{array}$ & $\begin{array}{l}-0.080 \\
-0.029 \\
-0.065\end{array}$ & $\begin{array}{l}-2.02 \\
-4.98 \\
-4.29\end{array}$ \\
\hline $\mathrm{s}$ & INC (S) & 0.001 & 3.89 & 0.0005 & 2.72 \\
\hline $\mathrm{CON}$ & $\begin{array}{l}\text { JCONST } \\
\text { BCONST } \\
\text { LCONST }\end{array}$ & $\begin{array}{l}1.854 \\
0.593 \\
2.265 \\
\end{array}$ & $\begin{array}{c}4.90 \\
1.53^{*} \\
5.48\end{array}$ & $\begin{array}{l}-0.276 \\
-1.742 \\
-1.133\end{array}$ & $\begin{array}{l}-0.83^{*} \\
-4.74 \\
-3.05\end{array}$ \\
\hline \multicolumn{2}{|c|}{$\begin{array}{c}D F \\
\lambda^{2} \\
L(\theta) \\
\rho\end{array}$} & \multicolumn{2}{|c|}{$\begin{array}{c}8 \\
339 \\
-637.968 \\
0.206\end{array}$} & \multicolumn{2}{|c|}{$\begin{array}{c}8 \\
349 \\
-512.070 \\
0.237\end{array}$} \\
\hline \multicolumn{2}{|c|}{$\%$ HIT } & \multicolumn{2}{|c|}{64.10} & \multicolumn{2}{|c|}{67.81} \\
\hline \multicolumn{2}{|c|}{ SAMPLES } & \multicolumn{2}{|c|}{860} & \multicolumn{2}{|c|}{702} \\
\hline
\end{tabular}

* not significant at $5 \%$ Level of Significance

Table 11 Mode Choice Models with Panel Samples

\begin{tabular}{|c|c|c|c|c|c|c|c|}
\hline \multicolumn{2}{|l|}{$\therefore$} & \multicolumn{2}{|c|}{1987 TS } & \multicolumn{2}{|c|}{1990 PS } & \multicolumn{2}{|c|}{ POOLED } \\
\hline \multicolumn{2}{|c|}{ Variables } & $\theta$ & $t$-value & $\theta$ & $t$-value & $\theta$ & t-value \\
\hline LOS & $\begin{array}{l}\text { OVTT (G) } \\
\text { IVTT (G) } \\
\text { TOC (G) }\end{array}$ & $\begin{array}{l}-0.223 \\
-0.002 \\
-0.019\end{array}$ & $\begin{array}{l}-1.75^{*} \\
-0.17^{*} \\
-0.81^{*}\end{array}$ & $\begin{array}{l}-0.123 \\
-0.020 \\
-0.136\end{array}$ & $\begin{array}{l}-1.39^{*} \\
-1.34^{*} \\
-2.95\end{array}$ & $\begin{array}{l}-0.116 \\
-0.008 \\
-0.054\end{array}$ & $\begin{array}{l}-2.08 \\
-0.92^{*} \\
-2.95\end{array}$ \\
\hline$S$ & INC (S) & 0.002 & 2.50 & 0.001 & -2.02 & 0.002 & -3.25 \\
\hline $\mathrm{CON}$ & $\begin{array}{l}\text { JCONST } \\
\text { BCONST } \\
\text { LCONST }\end{array}$ & $\begin{array}{l}1.837 \\
0.526 \\
2.556\end{array}$ & $\begin{array}{c}2.04 \\
0.57^{*} \\
2.59\end{array}$ & $\begin{array}{l}-0.701 \\
-1.997 \\
-1.474\end{array}$ & $\begin{array}{l}-0.77^{*} \\
-2.03 \\
-1.52^{*}\end{array}$ & $\begin{array}{c}0.710 \\
-0.599 \\
0.606\end{array}$ & $\begin{array}{l}1.15^{*} \\
-0.74^{*} \\
0.95^{*}\end{array}$ \\
\hline \multicolumn{2}{|r|}{$\begin{array}{c}D F \\
\lambda^{2} \\
L(\theta) \\
\rho\end{array}$} & \multicolumn{2}{|c|}{$\begin{array}{c}8 \\
65 \\
-107.865 \\
0.210\end{array}$} & \multicolumn{2}{|c|}{$\begin{array}{c}8 \\
121 \\
-106.341 \\
0.345\end{array}$} & \multicolumn{2}{|c|}{$\begin{array}{c}8 \\
132 \\
-219.650 \\
0.232\end{array}$} \\
\hline \multicolumn{2}{|c|}{$\%$ HIT } & \multicolumn{2}{|c|}{63.80} & \multicolumn{2}{|c|}{65.25} & \multicolumn{2}{|c|}{60.99} \\
\hline \multicolumn{2}{|c|}{ SAMPLES } & \multicolumn{2}{|c|}{141} & \multicolumn{2}{|c|}{$14 \mathrm{I}$} & \multicolumn{2}{|c|}{282} \\
\hline
\end{tabular}

* not significant at $5 \%$ Level of Significance 
Table 12 Similarity Index $\left(\mathrm{SI}_{\mathrm{ij}}\right)$

\begin{tabular}{||c|c|c|c|c|c|}
\hline \multirow{2}{*}{ Context $j$} & \multicolumn{5}{|c|}{ Context $\mathrm{i}$} \\
\cline { 2 - 6 } & $1987 \mathrm{TS}$ & $1990 \mathrm{TS}$ & 1987 PS & $1990 \mathrm{PS}$ & POOLED \\
\hline $1987 \mathrm{TS}$ & 1.00 & 0.83 & 0.95 & 0.55 & 0.76 \\
\hline $1990 \mathrm{TS}$ & 0.87 & 1.00 & 0.89 & 0.58 & 0.98 \\
\hline 1987 PS & 0.98 & 0.82 & 1.00 & 0.63 & 0.89 \\
\hline $1990 \mathrm{PS}$ & 0.60 & 0.69 & 0.61 & 1.00 & 0.67 \\
\hline POOLED & 0.89 & 0.96 & 0.91 & 0.65 & 1.00 \\
\hline
\end{tabular}

Table 13 shows the t-test statistics of the parameters between models. It reflects the instability of the parameters in the cross-sectional models with panel data. However, the degree of instability has declined slightly as shown by the decrease in the number of insignificant parameters when the panel data were pooled. This suggests that given a sizeable number of panel samples, the stability of the parameters will be enhanced.

Table 13 Results of $\mathrm{t}$-test

\begin{tabular}{|c|c|c|c|c|c|c|c|}
\hline \multicolumn{2}{|c|}{ VARIABLE } & 87TS-90TS & 87PS-90PS & 87TS-87PS & 90TS-90PS & 87PS- & 90PS- \\
\hline $\mathrm{L}$ & OVTT & -2.35 & $-1.03 *$ & $0.56^{*}$ & $0.68^{*}$ & $-1.26^{*}$ & $0.04^{*}$ \\
\hline 0 & IVTT & 2.45 & $1.35^{*}$ & -1.09 & $=1.09^{*}$ & $0.62^{*}$ & $-1.06^{*}$ \\
\hline$S$ & TOC & 5.28 & 3.19 & $1.53^{*}$ & 3.10 & $1.72 *$ & -2.68 \\
\hline S & INC & 2.57 & $0.83^{*}$ & $-1.76^{*}$ & -2.52 & $0.23^{*}$ & $-0.77^{*}$ \\
\hline C & JCONST & 5.95 & 2.80 & $0.04^{*}$ & $0.89^{*}$ & $1.59^{*}$ & -1.97 \\
\hline 0 & BCONST & 6.18 & 2.64 & $0.13^{*}$ & $0.49^{*}$ & $1.52^{*}$ & -1.83 \\
\hline$N$ & LCONST & 8.62 & 4.12 & $-0.55^{*}$ & $0.66^{*}$ & 2.51 & -2.70 \\
\hline
\end{tabular}

* not significant at $5 \%$ Level of Significance

Finally, the time transferability of the models is evaluated using the Hotelling's $\mathrm{T}^{2}$ test (Table 14). In the out-set,, all the models may be rejected in terms of time transferability by considering the degrees of freedom. However, the models with panel data reflect better transferability compared to the models with cross-sectional data. The panel model (POOLED) showd that by increasing the panel sample size, time transferability of mode choice models will be improved.

Table 14 Hotelling's Generalized $\mathrm{T}^{2}$ Test

\begin{tabular}{|c|c|c|c|}
\hline $\begin{array}{c}\text { MODELS } \\
\text { COMPARED }\end{array}$ & $\mathrm{T}^{2}$ & $\mathrm{~F}_{0}$ & d.f. \\
\hline 87TS-90TS & 4731.86 & 673.38 & 7,1554 \\
87PS-90PS & 278.23 & 38.75 & 7,234 \\
87TS-87PS & 281.31 & 39.95 & 7,993 \\
90TS-90PS & 472.99 & 67.09 & 7,835 \\
87PS-POOLED & 127.95 & 17.99 & 7,375 \\
90PS-POOLED & 240.97 & 33.88 & 7,375 \\
\hline
\end{tabular}


This chapter shows that mode choice models can be better estimated using panel data given the changing socio-economic attributes of the same people over time. The differences of the models with panel data shown in Table 12 can be due to the changes over time. The mode choice models with panel data notably the panel model reveals that despite the changing socio-economic attributes of the panel members, they still have the same levels of mode choice decisions as indicated in the analysis of the models particularly with the higher degree of time transferability of the models with panel data.

\section{CONCLUDING REMARKS}

This paper shows the potential of panel data not only in following the changes in socio-economic attributes but also in analyzing the association of changes in the attributes and in mode choice modeling. The logit log-linear and disaggregate logit models reveal that despite the changing conditions of the panel samples they tend to still have the same degree of decisions with respect to their socio-economic attributes and mode choice behavior.

Future directions of this study include: a) more analysis on the issue of serial correlation; and b) exploration of the practical application of panel analysis in examining transport policies and measures such as introduction of mass transit systems and TDM schemes in developing countries.

\section{REFERENCES}

1) Ben-Akiva M. \& Lerman S. (1985), Discrete Choice Analysis: Theory and Application to Travel Demand, MIT Press.

2) Goodman L. A., 1978, Analyzing Qualitative/Categorical Data. Log-linear Models and Latent Structure Analysis.

3) Kitamura R., 1990, Panel Analysis in Transportation Planning: An Overview, Transpn. Res.-A, Vol. 24A, 401 - 415.

4) Lidasan H. S., Tamura T., Ishida H. \& Kurokawa T., 1992, Introducing Panel Analysis in the Study of Travel Behavior in Metro Manila, Proceedings of the Japan Society of Civil Engineers' Conference, in Japanese.

5) Lidasan, 1995, A Study on the Conduct-ivity of Panel Survey and Applicability of Panel Data in the Analysis of Variations in Socio- economic Characteristics and "ToWork" Travel Behavior Analysis in Developing Countries - Metro Manila: A Case Study, unpublished dissertion.

6) Seber G.A.F., 1983, Multi-variate Analysis, John Wiley \& Sons.

APPENDIX 1: LRT Line 1: Light Rail Transit in Metro Manila opened in 1984. It has a length of 15 kilometers and carries 350,000 persons per day. LRT Line 2 is now on planning stage.

APPENDIX 2: Indices of Model Comparisons

Similarity Index: describes relation among similarly specified models as to their $\boldsymbol{\rho}^{2} \mathrm{~s}$ and takes the values between 0 and 1 . The closer the index to 1 the more similar the models are. It takes the form $\mathrm{SI}_{\mathrm{ij}}{ }^{2}=\rho_{\mathrm{i}}{ }^{2} / \rho_{\mathrm{j}}{ }^{2}=\left\{1-\mathrm{L}_{\mathrm{i}}\left(\theta_{\mathrm{j}}\right) / \mathrm{L}_{\mathrm{i}}\left(0_{\mathrm{i}}\right)\right\} /\left\{1-\mathrm{L}_{\mathrm{j}}\left(\theta_{\mathrm{j}}\right) / \mathrm{L}_{\mathrm{j}}\left(0_{\mathrm{j}}\right)\right\}$ 
where $L_{i}\left(\theta_{j}\right)=\log$-likelihood for a model with parameters estimated in context $j$ and applied in context $\mathrm{j}$, and $\mathrm{L}_{\mathrm{i}}\left(\mathrm{O}_{\mathrm{i}}\right)=\log$-likelihood for a zero base model in context $\mathrm{i}$.

Parameter Significance of Models: a test on the significance of parameters among models using the following t-test statistic $t=\beta_{1}-\beta_{2} /\left\{s \sqrt{ }\left(1 / n_{1}+1 / n_{2}\right)\right\}$ where $s=\sqrt{ }\left\{\left(n_{1}-1\right) n_{1} \sigma_{1}{ }^{2}+\right.$ $\left.\left(n_{2}-1\right) n_{2} \sigma_{2}^{2}\right\} /\left(n_{1}+n_{2}-2\right) ; \beta_{1}, \beta_{2}=$ estimated parameters; $n_{1}, n_{2} \quad$ = sample sizes of compared models' data set; $\sigma_{1}{ }^{2}, \sigma_{2}{ }^{2}=$ variances

Hotelling's Generalized $\mathbf{T}^{2}$-Test: a test determining the transferability of models. If $\boldsymbol{\Sigma}_{\mathbf{1}}=\boldsymbol{\Sigma}_{\mathbf{2}}$ $=\Sigma$, then $\left.\mathbf{T}^{2}=(\mathbf{X}-\mathbf{Y})^{\prime}\{1 / \mathrm{m}+1 / \mathrm{n}) \Sigma\right\}^{-1}(\mathbf{X}-\mathbf{Y})$; where:

$\mathbf{X}, \mathbf{Y}=$ sample sizes of models, $\boldsymbol{\Sigma}=$ unbiased estimator of $\boldsymbol{\Sigma}$ Let $\boldsymbol{\Sigma}_{1}$ and $\boldsymbol{\Sigma}_{2}$ be unbiased estimators of $\Sigma_{1}$ and $\Sigma_{2}$, respectively, then unbiased estimator $\boldsymbol{\Sigma}_{\text {is }}$ given by $\boldsymbol{\Sigma}=\left\{(\mathrm{m}-1) \boldsymbol{\Sigma}_{1}+\right.$ $\left.(\mathrm{n}-1) \Sigma_{2}\right\} /(\mathrm{m}+\mathrm{n}+2)$. If $\mathbf{H}_{\mathrm{o}}: \boldsymbol{\mu}_{1}=\boldsymbol{\mu}_{2}$ is true, $\mathbf{F}_{\mathrm{o}}=\{(\mathrm{m}+\mathrm{n}-\mathrm{k}-1) /[(\mathrm{m}+\mathrm{n} 2) \mathrm{k}]\} \mathbf{T}^{2}-$ $\mathbf{F}_{k, m+n-k-1}$ when $\mathbf{F}_{\mathbf{o}}>\mathbf{F}_{\mathrm{k}, \mathrm{m}+\mathrm{n}-\mathrm{k}-1}(\alpha)$, the null hypothesis is rejected at the $\alpha$ significance level.

パネルテータを用いたメトロマニラにおける勤務地移動、交通機関選択行動の分析

H.S.Lidasan, 石田東生、黒川洸、谷口守、大野栄治

発展途上国においては社会経済属性の変化が非常に急激であるため、個人を経年的に追跡 した質の高いパネルテータを用いて社会経済属性の変化や交通行動分析を行うことの意 義は大きい。本研究はマニラ大都市圈を対象に、パネルテータを用いることによって個人 の通勤交通手段変更と勤務地移動をログリニアモテルにより分析し、それぞれの変化の要 因を明らかにした。また、個人の交通機関選択行動についても非集計ロジットモデルを用 いて検討した。クロスセクション分析に比して、パネルサンプルをプールして推定した方 がパラメー夕推定值の時間的安定性が高いことが確認された。

\section{ANALYSIS OF WORKPLACE AND MODE CHOICE BEHAVIOR IN METRO MANILA EMPLOYING PANEL DATA \\ Hussein S. LIDASAN, Haruo ISHIDA, Takeshi KUROKAWA, Mamoru TANIGUCHI,}

The theoretical advantages of panel analysis make it attractive considering the changing socio-economic conditions in developing countries. This study examines the use of panel data set in generating models of workplace and mode choice decisions. The log-linear models show that panel members tend to remain in their workplaces inspite of changing socio-economic conditions. Likewise, the mode choice panel model suggests that despite changing socioeconomic attributes of panel members, they still have the same level of decision over time. Finally, the degree of transferability of mode choice models is shown to be higher with panel data than cross-sectional data. 